\title{
Isolation and Antibiotic Susceptibility Profiling of Enteric Bacteria from Homemade and Industrial Made Meat Pies Sold in Harare CBD, Zimbabwe
}

Gufe Claudious $^{1 *}$, Marumure Jerikias ${ }^{2}$, Hodobo Tinashe ${ }^{1}$, Jongi Gilbert ${ }^{1}$, Chirau Delay ${ }^{1}$, Musari Shuvai ${ }^{1}$, Katsande Peter ${ }^{1}$ Mbonjani Bernard ${ }^{1}$, Ncube Ruvimbo ${ }^{1}$, Museredza Revison ${ }^{1}$, Gadaga Biko ${ }^{1}$, Sibanda Zwelabo ${ }^{3}$, Munyanyi Tarusenga ${ }^{1}$

${ }^{1}$ Division of Veterinary Services, Diagnostics and Research Branch, Central Veterinary Laboratories, P. Bag CY551, Causeway, Harare, Zimbabwe ${ }^{2}$ Department of Biological Sciences, Faculty of Science, Bindura University Science Education, P. Bag 1020, Bindura, Zimbabwe

${ }^{3}$ Division of Veterinary Services, Diagnostics and Research Branch, Bulawayo Provincial Veterinary Laboratory, P O Box RY41, Raylton, Bulawayo, Zimbabwe

DOI: $10.36347 / \mathrm{sajb} .2020 . \mathrm{v} 08 \mathrm{i} 01.001$

| Received: 28.12.2019| Accepted: 04.01.2020| Published: 14.01.2020

*Corresponding author: Gufe Claudious

Abstract

Original Research Article

Ready-to-eat foods such as meat pies are susceptible to microbial contamination and street vended foods have become a global health problem. The objectives of this cross-sectional study were: i) Isolation and identification of enteric bacteria from meat pies; ii) To estimate the total coliforms and E.coli counts from the meat pies and iii) To determine the antimicrobial susceptibility patterns of detected enteric bacteria. A total of 120 meat pies were collected in Harare CBD between November 2018 and April 2019 and were tested using standard microbiological methods. Antibiotic susceptibility testing for the identified enteric bacteria was performed using the Kirby-Beur disk agar diffusion method. Four bacterial species were isolated which were E. coli, Proteus mirabilis, Staphylococcus aureus and Klebsiella pneumoniae. The overall prevalence rates of the bacterial genera isolated were calculated and Escherichia coli had the highest prevalence rate of $54.3 \%$ followed by S. aureus $25.7 \%$ followed by Klebsiella pneumoniae $11.4 \%$ and Proteus mirabilis $8.6 \%$. Microbiological quality was unsatisfactory in pies that were homemade with total coliforms and $E$. coli counts ranging from $2.0 \times 10^{2}$ to $1.0 \times 10^{5}$. All the enteric bacteria isolated were susceptible to sulphamethoxazole/Trimethoprim and gentamycin with varying antibiotic resistance against the other antibiotics tested. The pies were contaminated with enteric bacteria indicating non-enforcement of inspection and lack of maintenance of standard relation to hygienic quality of meat pie. This deviation from bacteriological quality standards of the meat pies poses potential risks to consumers. Total coliforms and $E$. coli count from industrially manufactured meat pies were 0 $\left(<10^{1}\right)$ and were suitable for human consumption. Continuous monitoring of proper hygienic and sanitary conditions in each activity from pre-preparation to cleaning is required in homemade and street vended ready-to-eat foods. More research is needed to build a lot of literature on the microbiological hazards associated with ready to eat food. It is concluded that measures should be taken by responsible authorities to ensure that food quality and safety standards are improved and adhered to in order to reduce public health risks.

Keywords: Antibiotic-resistant, meat pie, enteric bacteria.

Copyright @ 2020: This is an open-access article distributed under the terms of the Creative Commons Attribution license which permits unrestricted use, distribution, and reproduction in any medium for non-commercial use (NonCommercial, or CC-BY-NC) provided the original author and source are credited

\section{INTRODUCTION}

Implementation of food safety programmes is important to protect the health of the consumer. Food safety management system is one of the programmes that identifies and controls food safety hazards at every stage of food processing through a holistic system of controls which includes Hazards Analysis Critical Control Point system; daily monitoring and evaluation of food handlers and environment; and efficient, accurate record-keeping [1]. Food safety management system can be implemented successfully in industrially made meat pies, but this is not the case in homemade meat pies where the production of these pies cannot be monitored.

Due to economic hardship in Zimbabwe, many people have ventured into the informal production of ready-to-eat products such as Meat pie [2]. The meat pie is a ready-to-eat food made up of dough (flour) and a filling of meat and other ingredients [3, 4]. The meat pie is a good source of proteins, sodium and carbohydrates. Meat pies are contaminated with microorganism not intentionally introduced which can affect the safety of the meat pies. Meat pies are susceptible to contamination 
along the value chain. The presence of bacteria especially enteric organisms is an indication of unhygienic or poor sanitary practices during processing, packaging, storage and marketing of the endpoint product. The meat/minced meat used on meat pie preparation can be contaminated on slaughter process as cattle regarded as the main reservoir of the E.coli in the gastrointestinal tracts, the carcass becomes contaminated through faeces [5].

Ground or tenderized meats are riskers than intact cuts of meat because bacteria can be mixed throughout the meat in the grinding process or during tenderization [6]. New bacteria can be introduced to the meat or food from the environment, through handling and processing [2]. Bacteria will spread into the centre of the food, where they will be less easily destroyed on cooking [2]. The pathogen reduction should be available during the production process such as heating/cooking [5].

The consumption of meat pies contaminated by enteric bacteria can result in food-borne illnesses especially in immunocompromised individuals. Food-borne illness is a major problem in developing countries due to poor sanitation and relaxation of food safety programmes [7, 8]. Bacteria that are mainly associated with food-borne diseases are Clostridium perfringens, Listeria monocytogenes, Campylobacterium species, Salmonella species and E. coli [9]. Street foods have been implicated in the spread of foodborne infections in some parts of the developing countries including South Africa, Swaziland, Malawi, Central African Republic, Cameroon, Nigeria, Ivory Coast and Kenya [7, 10-12]. Foodborne illnesses such as diarrhoea and typhoid have been on the rise in Zimbabwe and there are inadequate diagnostic facilities, leading to inadequate investigation of outbreaks and the subsequent gross under-reporting of food-borne illnesses. Food or water remains the main vehicle for many of diarrhoeal illnesses in developing countries [13].

Street food vending plays a vital role in providing affordable and easily accessible food to travellers and urban dwellers [14]. Street food vending is now a common practise in Zimbabwe and these street vendors are unlicensed and untrained in hygienic handling of food, poorly educated and operate under poor sanitary conditions with little or no know-how about the dangers of food-related illnesses [13]. Constant assessment of the microbial quality of ready-to-eat foods is needed to ensure that people are eating safe food. Vendors and retailers should focus more on hygienic practices during food processing and packaging [15]. Food safety compliance with approved standards should be enforced by regulatory authorities. Antibiotic-resistant enteric bacteria are transmitted to humans via contaminated food, water, nails and fingers, showing the importance of faecal-oral transmission route [16]. The main aim of this study was to determine the prevalence of antibiotic-resistant enteric bacteria from homemade and industrial made meat pies sold in Harare CBD, Zimbabwe.

\section{MATERIALS AND METHOD Study Design and Sample Collection}

A cross-sectional study was conducted to assess enteric bacteria contamination of meat pies made in homes and industry between November 2018 and April 2019 and to determine the prevalence of antibiotic-resistant enteric bacteria. Sixty meat pies from homemade and sixty industrially manufactured meat pies were purposively sampled. This involved choosing small targeted meat pies being sold in supermarkets, takeaways and homemade from street vendors. Samples were collected randomly from three ranks in the Harare CBD namely Copacabana, Market Square and Fourth Street bus terminus. Forty samples were randomly collected from each selected places, ten samples were collected from takeaways, ten from supermarkets and twenty from homemade street vendors. Twenty samples were collected and tested per month. The samples were bought and placed in clean plastics. The samples were packed in a cooler box with ice packs and transported to the Central Veterinary Laboratory for processing.

\section{METHOD}

\section{Isolation and Identification of Enteric Bacteria}

Ten (10) grams of each meat pie was weighed and placed into $90 \mathrm{mls}$ of peptone water. The mixture was homogenised and incubated at $37^{\circ} \mathrm{C}$ and $44^{\circ} \mathrm{C} \quad 18-24$ hours. After incubation, a loopful of the broth was inoculated onto Blood Agar and MacConkey Agar. The inoculated plates were incubated for $18-24$ hours at $37^{\circ} \mathrm{C}$ and $44^{\circ} \mathrm{C}$. Enteric bacteria were identified using colony morphology, gram staining, standard biochemical tests and carbohydrates fermentation [17]. The sterilized meat pie was used as a negative control and during biochemical testing different ATCC organisms (Staphylococcus aureus ATCC 33862, Escherichia coli ATCC 25922 and Klebsiella pneumoniae ATCC 13883) were used as positive controls.

\section{Enumeration of $\boldsymbol{E}$. coli and coliforms}

Ten (10) grams of the homogenate meat pies samples suspended in $90 \mathrm{mls}$ of buffered phosphate saline were serially diluted up to $10^{-7}$. About $1 \mathrm{ml}$ of each sample was plated on MacConkey agar and incubated at $37^{\circ} \mathrm{C}$ and $44^{\circ} \mathrm{C}$ for $18-24$ hours. Suspected colonies of coliforms and $E$. coli were counted and were confirmed using gram staining and biochemical tests [17]. Quality control reference materials were used parallel with the samples tested and results were only accepted if the reference materials produce the expected results. 


\section{Antimicrobial Sensitivity Testing \\ Disc Diffusion Assay}

The Kirby-Bauer disc diffusion method was used to determine the susceptibility patterns of the isolated bacteria species to antibiotics. Few colonies of the bacterial isolates were picked and emulsified into saline water until the turbidity of $0.5 \mathrm{McFarland}$ was reached. A sterile swab was dipped in the test suspension and streaked in three directions over the entire surface of the agar and a final sweep with the swab was made against the agar around the rim of the Mueller Hinton Agar plate. Antibiotic impregnated discs (Oxoid) were applied onto the plates using an antibiotic dispenser. The plates were incubated for 24 hours at $37^{\circ} \mathrm{C}$. The antibiotics used were Ertapenem 10 $\mu \mathrm{g}$, Vancomycin

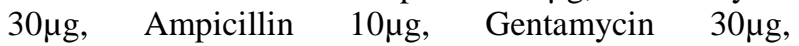
Erythromycin $15 \mu \mathrm{g}$, Tetracycline $30 \mu \mathrm{g}$, Ceftriaxone

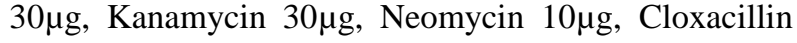
$5 \mu \mathrm{g}$, and Sulfamethoxazole $25 \mu \mathrm{g}$ (Oxoid, Germany). The zones of inhibition were measured and the results were interpreted as resistant, intermediate and sensitive to the different antibiotics that were used using the WHONET [18].

\section{DATA ANALYSIS}

Percentage prevalence of isolated bacteria were calculated as the number of times the bacterium detected over the total number of bacterial isolates detected. Chi-square test in $\mathrm{R}$ software was used to compare if there was a statistically significant difference between the counts of meat pies sampled at three different ranks in Harare CBD.

\section{RESULTS \\ Isolation and Identification of Enteric Bacteria}

Four bacteria genera were isolated from the meat pies bought from the homemade street vendors and no single bacterial genera were detected in industrially made meat pies. These bacteria were tentatively identified as Staphylococcus aureus, Escherichia coli, Proteus mirabilis and Klebsiella pneumoniae using colony morphology results, gram staining and biochemical tests as indicated in Table-1. These bacteria were only detected in some of the meat pies from homemade street vendors at the three different places in Harare CBD.

Table-1: Colony morphology, gram stain and biochemical tests characterization of isolated bacteria

\begin{tabular}{|c|c|c|c|c|}
\hline Test & Result & Result & Result & Result \\
\hline Blood Agar & $\begin{array}{l}\text { Grey round large } \\
\text { non-haemolytic } \\
\text { colonies }\end{array}$ & $\begin{array}{l}\text { Grey mucoid } \\
\text { non-haemolytic colonies }\end{array}$ & $\begin{array}{l}\text { Grey swarming } \\
\text { non-haemolytic } \\
\text { colonies }\end{array}$ & $\begin{array}{l}\text { Round white,/yellow } \\
\text { gamma haemolytic } \\
\text { colonies }\end{array}$ \\
\hline MacConkey Agar & $\begin{array}{l}\text { Round large pink } \\
\text { colonies }\end{array}$ & Round large pink colonies & Round pale colonies & $\begin{array}{l}\text { Tiny pink round } \\
\text { colonies }\end{array}$ \\
\hline Gram staining & Negative rods & Negative rods & Negative rods & Positive cocci \\
\hline Catalase & Positive & Positive & Positive & Positive \\
\hline Oxidase & Negative & Negative & Negative & Negative \\
\hline Coagulase & Not Tested & Not Tested & Not Tested & Positive \\
\hline Motility & Positive & Negative & Positive & Not Tested \\
\hline Urease & Negative & Positive & Positive & Positive \\
\hline Indole & Positive & Negative & Negative & Not Tested \\
\hline Citrate & Negative & Positive & Negative & Not Tested \\
\hline Triple iron Sugar & $\begin{array}{l}\text { Yellow butt, no } \\
\text { blackening }\end{array}$ & Yellow butt, no blackening & Blackening & Not Tested \\
\hline $\begin{array}{l}\text { Polymyxin B (300 } \\
\text { unit disks) }\end{array}$ & Not tested & Not tested & Not tested & Resistant \\
\hline Maltose & Positive & Positive & Negative & Positive \\
\hline Mannitol & Positive & Positive & Negative & Positive \\
\hline Trehalose & Not Tested & Not Tested & Not Tested & Positive \\
\hline Mannose & Positive & Positive & Negative & Positive \\
\hline Xylose & Positive & Positive & Positive & Negative \\
\hline Lactose & Positive & Positive & Negative & Not Tested \\
\hline Sucrose & Negative & Positive & Negative & Not Tested \\
\hline Inocitol & Negative & Positive & Negative & Not Tested \\
\hline Dulcitol & Negative & Negative & Negative & Not Tested \\
\hline Sorbitol & Positive & Positive & Negative & Not Tested \\
\hline Tentative Bacteria & E. coli & Klebsiella species & Proteus species & S. aureus \\
\hline
\end{tabular}

The overall prevalence rates of the bacterial species isolated were calculated and are shown in Fig-1. Escherichia coli has the highest prevalence rate of $54.3 \%$ (38 out of 70 isolates) followed by $S$. aureus
$25.7 \%$ (18 out of 70 isolates) followed by Klebsiella pneumoniae $11.4 \%$ ( 8 out of 70 isolates) and Proteus mirabilis has the least prevalence rate of $8.6 \%$ ( 6 out of 70 isolates). 


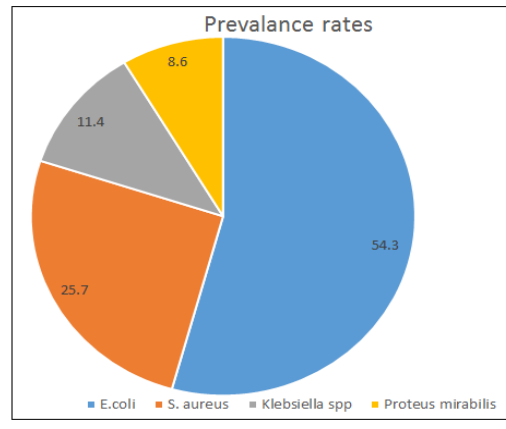

Fig-1: Overall prevalence rates of enteric bacteria isolated from homemade meat pies
Enumeration of coliforms and $\boldsymbol{E}$. coli.

Total coliforms and E. coli counts ranges from $2.0 \times 10^{2}$ to $1.0 \times 10^{5}$ indicating that all the meat pies with the counts were not suitable for human consumption. The meat pies with counts were from homemade pies only. Total coliforms and E. coli count from industrially manufactured meat pies were $0\left(<10^{1}\right)$ and were suitable for human consumption. There was no statistical significance difference in terms of the counts among the three sampled areas at $95 \%$ confidence intervals $(\mathrm{X}$-squared $=36.336, \mathrm{df}=36, \mathrm{p}$-value $=0.453>0.05)$.

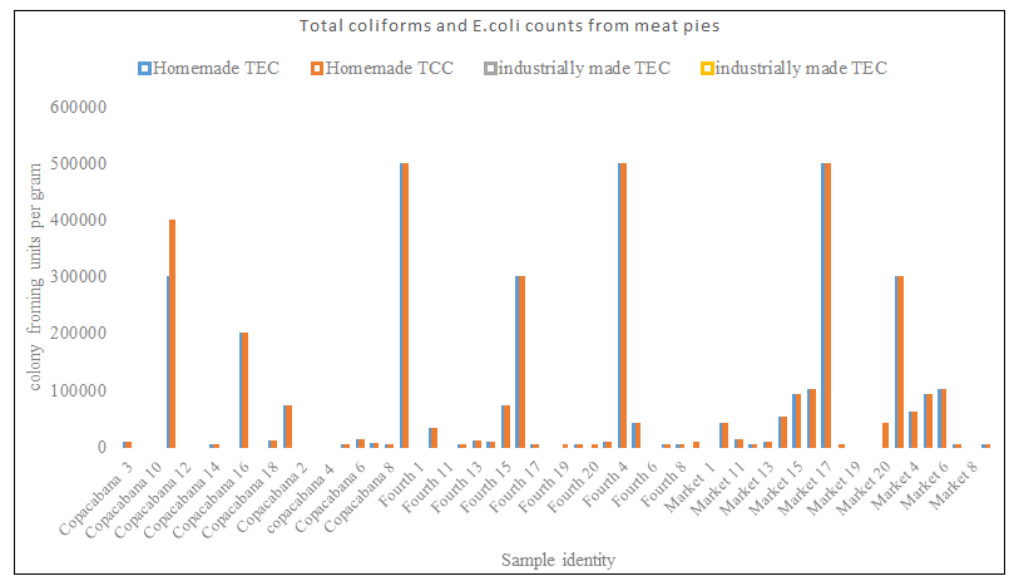

Fig-2: Total coliforms and $E$. coli counts from homemade meat pies and industrially made meat pies

\section{Antibiotic Susceptibility Testing}

All the isolated enteric bacteria were susceptible to sulphamethoxazole and gentamycin but showed varying resistance rates to the other antibiotics as shown in Table 2. Proteus mirabilis was resistant to only three antibiotics and susceptible to 8 antibiotics. Escherichia coli was $100 \%$ susceptible to 3 antibiotics, Klebsiella pneumoniae to two and $S$. aureus to five antibiotics (Table-2).

Table-2: Antibiotic resistance rates of the isolated bacteria

\begin{tabular}{|l|l|l|l|l|}
\hline Antibiotics & E. coli & Klebsiella & Proteus & S. aureus \\
\hline Penicillin & 100 & 100 & 0 & 68.4 \\
\hline Sulphamethoxazole & 0 & 0 & 0 & 39.5 \\
\hline Erythromycin & 65.8 & 2.6 & 0 & 44.7 \\
\hline Gentamycin & 0 & 0 & 0 & 0 \\
\hline Neomycin & 100 & 100 & 0 & 0 \\
\hline Kanamycin & 0 & 2.6 & 0 & 57.9 \\
\hline Cloxacillin & 65.8 & 2.6 & 0 & 26.3 \\
\hline Ertapenem & 71.1 & 2.6 & 100 & 0 \\
\hline Ceftriaxone & 78.9 & 2.6 & 100 & 73.7 \\
\hline Ampicillin & 94.7 & 100 & 0 & 55.3 \\
\hline Vancomycin & 100 & 100 & 0 & 0 \\
\hline Tetracycline & 80 & 68.4 & 100 & 84.2 \\
\hline
\end{tabular}

\section{DISCUSSION}

\section{Isolation and Identification of Enteric Bacteria from Industrially Made Meat Pies}

Enteric bacteria were absent in all the samples tested from the industrially made meat pies and this indicates adherence to the recommended food standards for human consumption. The absence of enteric bacteria may indicate good hygienic practices during preparation, packaging and storage. The meat pies tested were packed in airtight plastics containers and were served whilst hot in the formal supermarkets. So there was no contamination during transportation and selling of these pies. From these results, we can conclude that companies have constructed facilities that ease sanitation and proper 
equipment are available to employees to ensure successful completion of sanitation objectives.

\section{Isolation and identification of enteric bacteria from homemade meat pies}

The presence of E. coli and other enteric bacteria in meat pie sampled from homemade meat pies shows a deplorable state of poor hygienic and sanitary practices employed in the processing, packaging, storage and handling during selling [4, 19]. Usually, the presence of $E$. coli is an indication of faecal contamination of the water sources that were utilized in the processing of these food products and contamination through handling of the pies during production, packaging, selling and under processing that will left the organisms from the raw materials undestroyed [19, 20]. Escherichia coli, S. aureus, Proteus and Klebsiella are normal flora of animals and humans and their presence in meat pies indicates that the meat pies were excessively handled [13, 21]. Homemade meat pies' vendors violated the food safety practices by touching meat pies with bare hands after handling contaminated coins and notes and they didn't wear any apron or hair covers. The results of this study were in agreement with other researches who detected E.coli, coliforms and S. aureus in the food of animal origin [22-25]. These bacterial species have been implicated for foodborne infections worldwide. The bacteria are also present on the human body and can be introduced during the processing of meat pies, packaging, storage and handling for vendors and customers during selling [25].

\section{Enumeration of E.coli and coliforms from industrially made meat pies}

The counts were $<1.0 \times 10^{\wedge} 1$ (zero) meaning that the bacteria were absent and was conforming to the standards of enumeration of 0 colony forming units per gram (cfu/g) for $E$. coli and $<10^{2} \mathrm{cfu} / \mathrm{g}$ for coliforms count [4]. The research results show that meat pies from commercial producers are less likely to be contaminated due to good hygienic practices during manufacturing and selling. But the sample size was small and more studies need to be done.

\section{Enumeration of E.coli and coliforms from homemade meat pies}

Some homemade meat pies have total coliforms and E.coli counts above the recommended limits of $\leq 1.0$ $\times 10^{2}$ and $<1.0 \times 10^{1}$ respectively making them unsuitable for human consumption [26]. Coliforms and E.coli counts are reliable indicators of inadequate processing and post-processing contamination of homemade meat pies [8]. Our findings were also in agreement with other research findings done in southern Africa and the world over. The high coliform and E.coli counts are an indication of faecal contamination in homemade pies due to poor handling techniques beginning from the processing raw material to the finished meat pies and faecal contaminated water sources utilized in the processing of the meat pies [2]. The homemade meat pies and street vending in Harare CBD clearly showed an unacceptable state of meat pies consumed by people in Harare. There was no statistical difference between homemade pies being sold along the three main ranks in Harare CBD at $95 \%$ confidence intervals (X-squared $=$ 36.336 , df $=36$, p-value $=0.453>0.05$ ). Homemade meat pies manufacturers and vendors should practise good sanitation and food handling techniques to safeguard against the risks of the disease. Food safety trainings to homemade vendors by responsible authorities is a necessity. Ready-to-eat foods such as meat pies were reported to be the main cause of foodborne diseases such as E. coli O157: $\mathrm{H} 7$ infections which were first reported in the United of State of America outbreaks in 1991 [3, 27].

\section{CONCLUSION AND RECOMMENDATION}

The industrially made meat pies tested were free from enteric bacteria and were suitable for human consumption because they follow proper manufacturing and packaging sanitation and again they were served hot in supermarkets and takeaways. Unlike the ones from homemade street vendors which were contaminated with enteric bacteria and some have counts beyond recommended standards $\left(>10^{1}\right.$ and $>10^{2}$ for E.coli and coliforms respectively). We cannot totally rule out the possibility of infection by the sought bacterial pathogens in industrially made meat pies because the sample size was small and at the same time the samples were collected from formal manufacturers who followed a documented HACCP. The emergence of antibiotic-resistant bacteria is a public health concern and one health approaches in managing and reducing antibiotic resistance should be enforced regularly. Rigorous food hygiene, personal hygiene and environmental hygiene, use of clean water, adequate cooking and clean storage facilities and techniques are important in preventing the spread of enteric bacterial pathogens in the home, supermarkets, tuckshops and industries manufacturing ready-to-eat meat products. Street vendors need to be educated on the ways that reduce their ready cooked meat and food products from contamination. Street vendors should adhere to hygienic practices during production, packaging, storage and handling during selling, so as to prevent contamination of meat pies.

\section{REFERENCE}

1. National Environment Agency. Food Safety, Bulletin, Issue 3, January - June 2016, National Environment Agency, Singapore. 2016.

2. Clevence SY, Obinna CN, Shalom NC. Assessment of Bacteriological Quality of ready-to-eat food in Benin City Metropolis, Nigeria. 2009.

3. Centers for Disease Control and Prevention. Outbreaks of Escherichia coli O157: $\mathrm{H} 7$ associated with petting zoos - North Carolina, Florida, and 
Arizona, 2004 and 2005. Morbidity Mortality Weekly Report, 2005;54:1277-1280.

4. Frenzen PD, Drake, A, Angulo FJ. The economic cost of illness due to Escherichia coli 0157 infections in the United States. Journal of Food Protection, 2005;68(12):2623-2630.

5. Karch H, Tarr PI, Bielaszewska M. Enterohaemorrhagic Escherichia coli in human medicine. International Journal of Medical Microbiology. 2005 Oct 5;295(6-7):405-18.

6. Gansheroff LJ, O'Brien AD. Escherichia coli O157: $\mathrm{H} 7$ in beef cattle presented for slaughter in the US: higher prevalence rates than previously estimated. Proceedings of the National Academy of Sciences. 2000 Mar 28;97(7):2959-2961.

7. Koyange L, Ollivier G, Muyembe JJ, Kebela B, Gouali M, Germani Y. Enterohemorrhagic Escherichia coli O157, Kinshasa. Emerging infectious diseases. 2004 May;10(5):968-969.

8. Kumie A, Zeru K. Sanitary conditions of food establishments in Mekelle town, Tigray, north Ethiopia. Ethiopian Journal of Health Development. 2007;21(1):3-11.

9. Omemu AM, Edema MO, Bankole MO. Bacteriological assessment of street vended ready to eat (RTE) vegetables and pre-packed salad in Nigeria, Nig. J. Microbiol. 2005;19(1-2):497-504.

10. Gillespie I, Little CA, Mitchell R. Microbiological examination of cold ready-to-eat sliced meats from catering establishments in the United Kingdom. Journal of Applied Microbiology. 2000 Mar;88(3):467-474.

11. Fang TJ, Wei QK, Liao CW, Hung MJ, Wang TH. Microbiological quality of $18 \mathrm{C}$ ready-to-eat food products sold in Taiwan. International journal of food microbiology. 2003 Feb 15;80(3):241-250.

12. Mahale DP, Khade RG, Vaidya VK. Microbiological analysis of street vended fruit juices from Mumbai city, India. Internet Journal of Food Safety. 2008;10(9):31-34.

13. World Health Organization. The world health report 2002: reducing risks, promoting healthy life. World Health Organization; 2002.

14. Tambekar D, Jaiswal V, Dhanorkar D, Gulhane P, Dudhane M. Identification of microbiological hazards and safety of ready-to-eat food vended streets of Amravati City, India. Journal of Applied Biosciences. 2008:7:195-201.

15. Mensah P, Yeboah-Manu D, Owusu-Darko K, Ablordey A. Street foods in Accra, Ghana: How safe are they? Bull. World Health Organ. 2002;80(7):546-554.

16. Andargie G, Kassu A, Moges F, Tiruneh M, Huruy K. Prevalence of bacteria and intestinal parasites among food-handlers in Gondar town, northwest Ethiopia. Journal of health, population, and nutrition. 2008 Dec;26(4):451-455.

17. Sing A. Zoonoses - Infections affecting Humans and Animals: Focus on Public Health Aspects. Springer sciences + Business Media, Berlin, Germany. 2015.

18. hun Girma Z, Mamo Y, Ersado M. Species composition, distribution and relative abundance of large mammals in and around Wondo Genet Forest Patch, Southern Ethiopia. Asian Journal of Applied Sciences. 2012;5(8):538-51.

19. Rawat HK, Ganaie MA, Kango N. Production of inulinase, fructosyltransferase and sucrase from fungi on low-value inulin-rich substrates and their use in generation of fructose and fructo-oligosaccharides. Antonie Van Leeuwenhoek. 2015 Mar 1;107(3):799-811.

20. UNICEF: UNICEF Zimbabwe Cholera Outbreak Report (4 September - 21 November 2018). 23 November 2018.

21. Bryan MB, Caroline V, Madelon F. Safety of vendor-prepared foods: Evaluation of 10 processing mobile food vendors in Manhattan, Public Health Reports, 2003:(118):470-476.

22. Okonko IO, Ijandipe LA, Ilusanya OA, Donbraye-Emmanuel OB, Ejembi J, Udeze AO, Egun OC, Fowotade A, Nkang AO. Incidence of urinary tract infection (UTI) among pregnant women in Ibadan, South-Western Nigeria. African Journal of Biotechnology. 2009;8(23)

23. Ezeh A, Oyebode O, Satterthwaite D, Chen YF, Ndugwa R, Sartori J, Mberu B, Melendez-Torres GJ, Haregu T, Watson SI, Caiaffa W. The history, geography, and sociology of slums and the health problems of people who live in slums. The lancet. 2017 Feb 4;389(10068):547-58.

24. Feglo P, Sakyi K. Bacterial contamination of street vending food in Kumasi, Ghana. Journal of Medical and Biomedical Sciences, 2012:1(1):1-8.

25. Lovet $\mathrm{T}$, Kigigha. Bacteriological Quality Assessment of Meat Pie Sold in Yenagoa Metropolis, Nigeria. EC Nutrition. 2017;6:189-195.

26. Food Standards Australia New Zealand 2010. Compendium of Microbiological Criteria for Food, September 2018.

27. Centers for Disease Control and Prevention. Ongoing multistate outbreak of Escherichia coli serotype O157: H7 infections associated with consumption of fresh spinach-United States. Morbidity Mortality Weekly Report, 2006;55:1045-1046. 